\title{
Biological removal processes in aerobic granular sludge exposed to diclofenac
}

Vânia S. Bessa, Irina S. Moreira, Mark C.M. Van Loosdrecht \& Paula M.L. Castro

To cite this article: Vânia S. Bessa, Irina S. Moreira, Mark C.M. Van Loosdrecht \& Paula M.L. Castro (2021): Biological removal processes in aerobic granular sludge exposed to diclofenac, Environmental Technology, DOI: 10.1080/09593330.2021.1921048

To link to this article: https://doi.org/10.1080/09593330.2021.1921048

Accepted author version posted online: 26 Apr 2021.

Submit your article to this journal $₫$

山 Article views: 36

Q View related articles ¿

View Crossmark data 
Publisher: Taylor \& Francis \& Informa UK Limited, trading as Taylor \& Francis Group

Journal: Environmental Technology

DOI: 10.1080/09593330.2021.1921048

Biological removal processes in aerobic granular sludge exposed to diclofenac

Vânia S. Bessa ${ }^{1}$, Irina S. Moreira ${ }^{1 *}$, Mark C.M. Van Loosdrecht ${ }^{2}$, Paula M.L. Castro ${ }^{1}$

${ }^{1}$ Universidade Católica Portuguesa, CBQF - Centro de Biotecnologia e Química Fina - Laboratório Associado, Escola Superior de Biotecnologia, Rua Diogo Botelho 1327, 4169-005 Porto, Portugal

${ }^{2}$ Department of Biotechnology, Delft University of Technology, Building 58, Van der Maasweg 9, 2629

HZ Delft, The Netherlands

*Address for correspondence: I. S. Moreira, Universidade Católica Portuguesa, CBQF - Centro de Biotecnologia e Química Fina - Laboratório Associado, Escola Superior de Biotecnologia, Rua Diogo Botelho 1327, 4169-005 Porto, Portugal

Tel.: +351 225580001

Fax.: +351 225090351

E-mail: ismoreira@porto.ucp.pt

\section{Abstract}

Diclofenac/is a worldwide consumed drug included in the watch list of substances to be monitored according to the European Union Water Framework Directive (Directive 2013/39/EU). Aerobic granular sludge sequencing batch reactors (AGS-SBR) are increasingly used for wastewater treatment but there is scant information on the fate and effect of micropollutants to nutrient removal processes. An AGS-SBR fed with synthetic wastewater containing diclofenac was bioaugmented with a diclofenac degrading bacterial strain and performance and microbial community dynamics was analysed. Chemical oxygen demand, phosphate and ammonia removal were not affected by the micropollutant at $0.03 \mathrm{mM}(9.54 \mathrm{mg}$ $\mathrm{L}^{-1}$ ). The AGS was able to retain the degrading strain, which was detected in the sludge throughout after augmentation. Nevertheless, besides some adsorption to the biomass, diclofenac was not degraded by the 
augmented sludge given the short operating cycles and even if batch degradation assays confirmed that the bioaugmented AGS was able to biodegrade the compound. The exposure to the pharmaceutical affected the microbial community of the sludge, separating the two first phases of reactor operation (acclimatization and granulation) from subsequent phases. The AGS was able to keep the bioaugmented strain and to maintain the main functions of nutrient removal even through the long exposure to the pharmaceutical, but combined strategies are needed to reduce the spread of micropollutants in the environment.

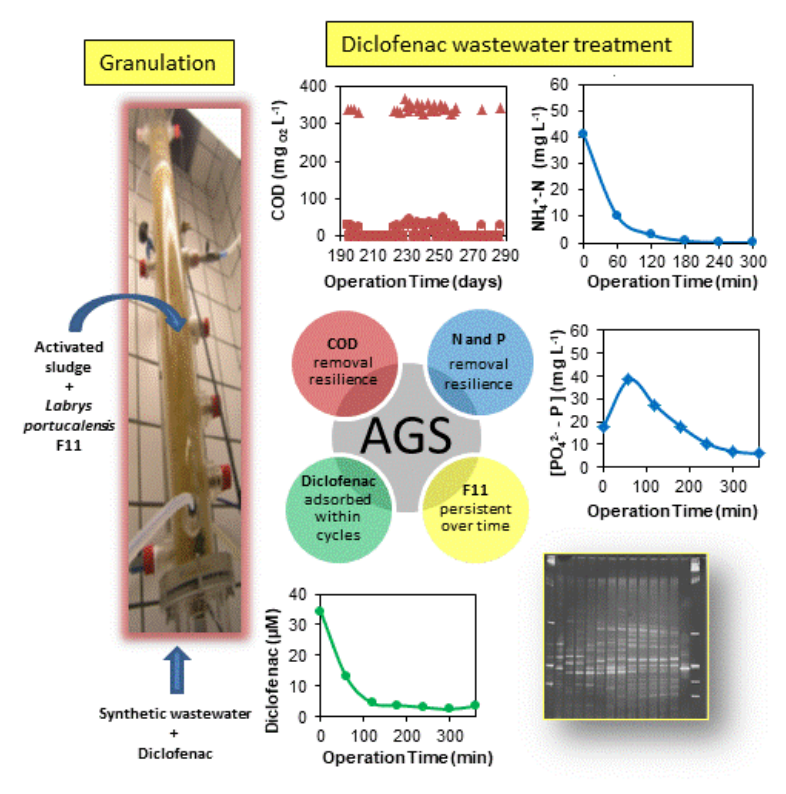

Keywords: Diclofenac; Labrys portucalensis F11; Aerobic Granular Sludge Sequencing Batch reactor; Bioaugmentation, Performance.

\section{Introduction}

In the last century, the growth of the global population and the increased life expectancy in developed countries have led to an increase in the consumption of pharmaceuticals [1]. These organic compounds are considered as emerging contaminants as they have the potential to enter in several compartments in the environment and cause adverse ecological and/or human health effects [2]. After metabolism and excretion, as unchanged compounds or as metabolites, in urine and/or faeces these micropollutants reach 
the wastewater treatment plants (WWTPs) through the sewage network [3]. Moreover, direct release may occur by improper dump of unused or expired drugs directly in toilet sinks or as solid waste. Conventional WWTPs are not designed to remove this kind of pollutants, which results in their release into the environment [4,5]. The existing physico-chemical removal processes (activated carbon, photolysis, radiation, advanced oxidation processes, ozone and chlorination) display some draw-backs as they are expensive and may result in unknown and potentially harmful by-products [2].

In the latest revision of the Water Framework Directive (Directive 2013/39/EU) a revised watch list of substances to be monitored [6] in the field of water policy has been proposed. It contemplates 17 organic compounds, including the nonsteroidal anti-inflammatory drug (NSAID) Diclofenac (2-(2-(2,6-dichlorophenylamino) phenyl)acetic acid). NSAIDs are of great concern due to their wide administration in humans and animals to treat inflammation and as pain relievers [7], being the largest group of over-thecounter drugs sold worldwide. Diclofenac is generally considered as a Contaminant of Emerging Concern (CEC), is one of the most persistent pharmaceuticals in the environment, and is removed with very low efficiency in WWTP [8]. Vieno and Sillanpää [71 reported mean concentrations of diclofenac in the influent of municipal WWTP between 0.11 and $2.3 \mu \mathrm{g} / \mathrm{L}$ and higher than $1 \mu \mathrm{g} / \mathrm{L}$ in the effluent. Higher concentrations of this compound at the effluent (up to $5.5 \mu \mathrm{g} / \mathrm{L}$ ) than in the influent, due to DCF deconjugation during the WWTP treatment, have been reported [9].

Aerobic granular sludge (AGS) technology is a growing biotechnology for the treatment of domestic and industrial wastewater [10]. The properties of AGS, such as excellent settling capacity due to compact and dense microbial structure, ability to perform simultaneously diverse biological processes (such as Chemical Oxygen Demand - COD, Nitrogen and Phosphate removal), resilience to toxicity due to the protection by a matrix of EPS, and long biomass residence time, confer advantages over more conventional wastewater treatments [11]. Further, the biomass immobilisation makes AGS prone to bioaugmentation [12]. Amorim et al. [13] evaluated the performance of AGS-SBR exposed to three fluoroquinolones, namely ofloxacin, norfloxacin and ciprofloxacin and verified that the compounds were firstly adsorbed to the AGS, being subsequently released to the medium in the following cycles. A study conducted by Kent and Tay [14] concluded that the removal of 17 $\alpha$ - ethinylestradiol, 4- nonylphenol and carbamazepine was initially carried by adsorption to AGS, transitioning to biodegradation when the active sites were saturated, indicating a sludge acclimatization to the contaminants. The ability of AGS- 
SBR to degrade fluoxetine shock loadings was assessed by Moreira et al. [15]. Overall, fluoxetine was firstly absorbed by AGS, followed by a desorption mechanism when the toxic compound was not present in the feed. The system proved to be robust towards fluoxetine shocks as it was able to resume its performance in terms of main biological processes after its feeding was ceased. The acclimatization of the seed sludge with the target contaminant has been indicated as a key step for efficient biodegradation in AGS reactors. Several reports claimed the successful biodegradation of recalcitrant compounds, such as phenol, 2-chlorophenol, 2,4,6-trichlorophenol, 2,4-dichlorophenol and p-nitrophenol, by acclimatized AGS [16-20]. Bioaugmentation with degrading strains has also proven to be an efficient strategy for the degradation of persistent compounds by AGS, including 2-fluorophenol, 2,4-dichlorophenoxyacetic acid and a mixture of chlorophenols and o-nitrobenzaldehyde [12,21,22].

In the present study an AGS-SBR bioaugmented with a bacterial strain - Labrys portucalensis F11- able to degrade pharmaceuticals, including diclofenac [23], was operated during 286 days intermittently supplied with diclofenac. The main aim of this study was to assess the persistence of the degrading strain within the AGS and to evaluate the biodegradation of the micropollutant by the bioaugmented granules while measuring the overall performance of the bioreactor for main nutrient removal processes. The microbial community dynamics were evaluated.

\section{Materials and methods}

\subsection{Chemicals and materials}

Acetonitrile was purchased from Merck (Darmstadt, Germany). Trifluoroacetic acid (99\%) and trimethylamine ( $\geq 99 \%)$ were obtained from Sigma-Aldrich (Steinheim, Germany). Ultrapure water was supplied by a Milli-Q Gradient A-10 (Millipore) system (18.2 M $\Omega \mathrm{cm}$, organic carbon $\leq 4 \mu \mathrm{g} / \mathrm{L})$. HPLC grade solvents were filtered with $0.45 \mu \mathrm{m}$ Glass microfiber filters (Whatman ${ }^{\mathrm{TM}}$ ). Diclofenac sodium salt was purchased from Sigma-Aldrich (Steinheim, Germany). Stock standard solutions of diclofenac were filtered on syringe nylon membrane filters $(0.22 \mu \mathrm{m}$ pore-size in order to sterilize) to sterile amber bottles and stored at $-20^{\circ} \mathrm{C}$. Minimal salts medium (MM) [24] and SBR influent media [25] were prepared with analytical-grade chemicals (Sigma-Aldrich Chemie, Steinheim, Germany; Merck, Darmstadt, Germany). Sodium acetate was purchased from Merck (Darmstadt, Germany). All other chemicals used in this study were analytical grade (Sigma-Aldrich Chemie, Steinheim, Germany; Merck, Darmstadt, Germany). 


\subsection{Cultivation conditions}

Labrys portucalensis F11 (GenBank/EMBL/DDBJ accession number AY362040) was selected due to its proven biodegradation ability towards diclofenac [23]. To obtain the inoculum for bioreactor bioaugmentation, pure cultures of Labrys portucalensis F11 were grown in flasks with mineral salts liquid medium containing $5.9 \mathrm{mM}$ of acetate and $0.03 \mathrm{mM}$ of diclofenac, which biodegradation was confirmed. The cultures were incubated on an orbital shaker $(120 \mathrm{rpm})$ at $25^{\circ} \mathrm{C}$. The optical density at $600 \mathrm{~nm}$ $\left(\mathrm{OD}_{600}\right)$ was followed to monitor the cellular growth.

\subsection{Reactor set up and operation}

An AGS-SBR operated at controlled temperature $\left(20 \pm 2^{\circ} \mathrm{C}\right)$ was set-up. The reactor was initially operated as a bubble column (Phase I, Table 1) with a working volume of $2.5 \mathrm{~L}$ (diameter $5.6 \mathrm{~cm}$ ). The reactor inoculum consisted in a mixture of $0.8 \mathrm{~L}$ activated sludge from the aeration tank of the municipal WWTP of Parada (Maia, Portugal) and 1.0 L of pure culture of the bacterial strain Labrys portucalensis strain F11 with an $\mathrm{OD}_{600}$ of ca. 0.755 . During phase I, a constant airflow of $4.0 \mathrm{~L} \mathrm{~min}^{-1}$ (superficial gas velocity of $1.51 \mathrm{~m} \mathrm{~min}^{-1}$ ) was kept and periodic feedings were applied with acetate $(5.9 \mathrm{mM})$ and 0.03 $\mathrm{mM}$ of DCF $\left(9.54 \mathrm{mg} \mathrm{L}^{-1}\right)$ in order to establish a selective pressure on the seed sludge and to favor the maintenance of the degrading strain. Diclofenac concentration was higher than what is normally found in domestic effluents and was used to assess the capacity of the reactor of biodegrading the compound through bioaugmentation and to assess the robustness of the reactor even if exposed to higher levels. At day 20, the reactor operation conditions were changed to an SBR mode - Phase II. During this phase, the reactor was operated in a 3-h cycle time with a $60 \mathrm{~min}$ non-mixed anaerobic feeding period, $112 \mathrm{~min}$ aeration, and 5 min effluent withdrawal; settling time was gradually decreased from $30 \mathrm{~min}$ to $3 \mathrm{~min}$. The volumetric exchange ratio was 0.56 with a hydraulic retention time of $5.4 \mathrm{~h}$. The $\mathrm{pH}$ was measured with a $\mathrm{pH}$ electrode and maintained at $7.1 \pm 0.1$ by dosing either $1 \mathrm{M} \mathrm{NaOH}$ or $1 \mathrm{M} \mathrm{HCl}$. The SBR influent media was supplemented with diclofenac at a final concentration of $0.03 \mathrm{mM}\left(9.54 \mathrm{mg} \mathrm{L}^{-1}\right)$. During phase III diclofenac was ceased from the influent feeding in order to evaluate the resilience of the bioaugmented strain and the system ability towards nutrient removal. The operating conditions for each phase are described in detail on Table 1. During the whole time, the bioreactor was protected from light in order to prevent photocatalytic degradation of diclofenac and algal growth. 


\subsection{Analytical methods}

Bioreactor influent and effluent samples were regularly withdrawn and filtered through nylon membrane syringe filters (0.45 $\mathrm{mm}$ pore-size) to remove biomass. Phosphate, ammonia, nitrate and nitrite concentrations in the filtrate were determined using specific commercial photometric test kits (Spectroquant ${ }^{\circledR}$, Merck Millipore, Massachusetts, EUA), according to manufacture instructions. Total suspended solids (TSS), volatile suspended solids (VSS), mixed liquor suspended solids (MLSS), mixed liquor volatile suspended solids (MLVSS) concentrations and sludge volume index (SVI) were determined according to Standard Methods [26]. The AGS bed volume was determined at the end of the settling period using a graduated scale placed on the reactor column. Diclofenac concentration was measured by HPLC according to a validated method previously described [27].

\subsection{Sampling of aerobic granular sludge for microbial analysis and degradation assays}

AGS samples were collected from the reactor during aeration phase. Then, the granules were crushed using a sterile potter and pestle. The resulting bacterial suspensions were used for plating, degradation assays, bacterial identification and DNA extraction for DGGE analysis. Moreover, an AGS sample was taken during phase IV in order to establish batch assays to assess the capacity of the bioaugmented AGS to biodegrade diclofenac.

\subsection{Bacterial isolates from AGS-SBR}

During phases III and VI, AGS samples were collected for isolation of bacteria able to degrade diclofenac. Using the streak-plate technique, different bacterial colonies were isolated based on size, morphology and pigmentation. For each isolate, streaking onto agar plates containing $0.03 \mathrm{mM}(9.54 \mathrm{mg}$ $L^{-1}$-diclofenac was made in order to evaluate their potential to grow in the presence of the pharmaceutical. For the isolates that had that ability, genomic DNA was extracted based on the heatshock extraction method.

Bacterial isolates were grouped according to species similarity, based on Random Amplified Polymorphic DNA (RAPD) profiles, following the procedure described in Amorim et al. [13]. Isolates displaying unique RAPD profiles were subsequently identified by 16S rRNA gene sequencing analysis. Amplification was performed with universal bacterial primers $27 \mathrm{~F}$ and $1492 \mathrm{R}$, as previously described 
[12]. The amplified fragments were sequenced by StabVida, Portugal. To determine the phylogenetic affiliation, similarity searches were performed using the BLAST program from the National Centre of Biotechnology Information website (http://www.ncbi.nlm.nih.gov/)

Isolates with ability to grow in the presence of diclofenac were inoculated into MM containing $0.03 \mathrm{mM}$ diclofenac as a sole carbon to evaluate the capacity to degrade the compound. Briefly, for each isolate (with an initial $\mathrm{OD}_{600}$ of ca. 0.05 ), $250 \mathrm{~mL}$ flasks containing $75 \mathrm{~mL}$ of a sterile $\mathrm{MM}$ supplemented with $0.03 \mathrm{mM}$ of diclofenac were established. Degradation was monitored for 30 days. Abiotic and adsorption control assays were established. In brief, abiotic controls consisted of sealed flasks containing MM supplemented with diclofenac; adsorption controls were conducted in flasks containing MM supplemented with DCF and inoculated with non-viable (i. e. autoclaved) cells of each isolate, separately. All the cultures were incubated at $25^{\circ} \mathrm{C}$ on a rotary shaker $(150 \mathrm{rpm})$. Experiments were performed in triplicate under sterile conditions and protected from light (to prevent photolytic degradation). Samples were taken at regular intervals to assess growth and diclofenac degradation. Purity of the cultures was evaluated through regular plating on NA plates.

\subsection{Total aerobic granular sludge microbial community analysis}

Genomic DNA from the crushed AGS samples was extracted using the UltraClean Microbial DNA Isolation Kit (MO BIO Laboratories, Inc., USA), according to the manufacturer's instructions. The extracted DNA was kept at $-20^{\circ} \mathrm{C}$. The PCR amplification of the highly variable V3 region of bacterial 16S rRNA gene fragments and separation of PCR-amplified fragments by DGGE was performed as described in Amorim et al. [13] using a DCodeTM Universal Mutation Detection System (Bio-Rad Laboratories, Richmond, CA, USA). DGGE profiles were analysed using Bionumerics software (Applied Maths, St-Martens-Laten, Belgium). Dendrograms were generated by Jaccard/UPGMA cluster analysis. Two different indexes were assessed using DGGE banding data: the Shannon's diversity index (H) [28] was used to estimate the diversity of bacterial communities and the Equitability index (E) was used to evaluate the dominance between species. The Equitability index (E) can range from near 0, pronounced dominance, to near 1, complete evenness. Selected DGGE bands were excised and the DNA sequencing was performed according to Amorim et al. [13]. Band sequences were compared using the BLAST software at the National Centre of Biotechnology Information website (http://www.ncbi.nlm.nih.gov/) for identification and phylogenetic classification. 


\subsection{Aerobic granular sludge diclofenac degradation ability in batch conditions}

Diclofenac biodegradation ability of AGS was evaluated in culture flasks. The experiments were set up in $250 \mathrm{~mL}$ flasks containing $80 \mathrm{~mL}$ of a sterile SBR influent medium with $5 \mathrm{~g}$ (wet weight) of AGS, 0.03 $\mathrm{mM}(9.54 \mathrm{mg} \mathrm{L}-1)$ of the target compound and periodic feeding with $5.9 \mathrm{mM}$ of acetate as a supplementary carbon source. All the cultures were incubated at $25^{\circ} \mathrm{C}$ on a rotary shaker $(150 \mathrm{rpm})$. Experiments were performed in triplicate under sterile conditions and protected from light. Abiotic and adsorption controls were also established. The biodegradation was monitored for 30 days.

\section{Results and discussion}

Diclofenac is a micropollutant of environmental concern frequently detected in wastewater influents, in this context is important to evaluate the fate and effect of this contaminant in wastewater treatment processes. In phase I, the reactor was inoculated with activated sludge from a municipal WWTP and the bacterial strain Labrys portucalensis F11, and operated as a bubble column for the acclimatization of the biomass to diclofenac. During phase II, the reactor operation conditions were changed to an SBR mode for the granulation process to occur. During phase III, diclofenac was not supplied in the influent feeding. In phases IV and V, the diclofenac was fed in intermittent mode, using different cycles' length. Diclofenac feeding was ceased in phase V. The fate of diclofenac and its effects on main biological processes COD-, N- and P-removal, and on the granular biomass properties and microbial community, were evaluated.

\subsection{AGS-SBR performance}

\subsubsection{Carbon and nutrient removal}

During phase I the biomass was acclimatized to diclofenac. During phases II and III, with and without diclofenac respectively, a stable COD removal was observed, with almost all COD consumed during the anaerobic feeding phase (data not shown). After resuming diclofenac supplementation, during phases IV to $\mathrm{VI}, \mathrm{COD}$ concentration after the feast period was low $\left(30 \mathrm{mg}_{\mathrm{O} 2} \mathrm{~L}^{-1}\right.$ in average), indicating that the presence of diclofenac did not affect COD uptake (Fig 1a). Throughout the entire SBR operation the COD removal efficiency remained very stable, always far below the emission limit value established by the European Commission of $125 \mathrm{mg} \mathrm{O}_{2} \mathrm{~L}^{-1}$ (council directive 91/271/EEC), with almost complete uptake 
during anaerobic phase. Some previous studies on pharmaceutical compounds had reported similar results in terms of overall COD removal, showing that AGS is capable of maintaining its performance in the presence of this kind of compounds. Amorim et al. [13] noticed a decrease in COD uptake when fluoroquinolones were present in the inlet stream, but the COD effluent quality was unaffected. Another study with AGS also reported that although COD removal effeciency was temporarily affected by the presence of chiral pharmaceuticals, the reactor was able to resume activity after ceasing the supply of pharmaceuticals, indicating a fast recovery of the AGS [29]. Kent and Tay [14] observed a stable COD removal efficiency (in average >92\%) in an AGS-SBR established for the treatment of 17 $\alpha$ - ethinylestradiol, 4- nonylphenol, and carbamazepine, with all of the three compounds being degraded, although carbamazepine to a lower extend. Moreira et al. [15] also noted that the presence of fluoxetine in the inlet feeding of an AGS-SBR did not compromise the COD removal as low COD concentrations on the effluent were observed.

One of the several advantages of the AGS-SBR technology is the ability of simultaneous N and P removal [30]. The phosphate (Fig $1 \mathrm{~b}$ ) concentration in the medium was $20 \mathrm{mg} \mathrm{L}^{-1} \mathrm{PO}_{4}{ }^{3-}-\mathrm{P}$ and after the anaerobic feeding period this was raised to around $40 \mathrm{mg} \mathrm{L}^{-1} \mathrm{PO}_{4}{ }^{3}-\mathrm{P}$; the effluent had ca $4.6 \mathrm{mg} \mathrm{L}^{-1}$ of $\mathrm{PO}_{4}{ }^{3-}-\mathrm{P}$. This trend was observed in all phases of the experimental period. An example of the $\left[\mathrm{PO}_{4}{ }^{3}-\mathrm{P}\right]\left(\mathrm{mg} \mathrm{L}^{-1}\right)$ concentration profile along the AGS-SBR operation (Phase V) is given in Fig 2a. The levels of phosphate released into the bulk medium during the feast period and the uptake during the famine period were in accordance with phosphate accumulating organisms' metabolism, indicating that the presence of diclofenac did not affect it. Different emerging contaminants may exert a variety of responses on the metabolism of these microorganisms. The present results are different from previous reports where the presence of other pharmaceutical compounds inhibited the phosphate release during anaerobic phase, although not interfering with its uptake during aerobic phase, resulting in good removal efficiencies $[14,15,31]$.

Regarding the nitrogen removal process, the ammonium concentration detected in the SBR after $1 \mathrm{hr}$ feeding was within the theoretically expected range, considering the dilution factor $\left(8.62 \mathrm{mg} \mathrm{L}^{-1}\right.$ of NH$_{4}{ }^{+}$$\mathrm{N}$, in average) and ammonium was almost fully removed $\left(0.5 \mathrm{mg} \mathrm{L}^{-1} \mathrm{NH}_{4}{ }^{+}-\mathrm{N}\right.$, in average in the effluent) during all reactor operation period, indicating a highly efficient nitrification (Fig 1c). This indicates that ammonia oxidizing bacteria were not affected by the presence of diclofenac throughout the entire 
operation of the reactor. Other reports also showed that ammonia oxidation was a stable process in the presence of pharmaceuticals $[13,14]$, indicating the potential of AGS towards this process in the presence of micropollutants. During phase V, a fluctuation in ammonium inlet concentration was observed, which did not affect its removal. From day 194 until day 233 (Phase IV and beginning of Phase V), nitrite was present both during famine period and in the treated effluent with an average concentration of $15 \mathrm{mg} \mathrm{L}^{-1}$ of $\mathrm{NO}_{2}^{-}-\mathrm{N}$ and $10 \mathrm{mg} \mathrm{L}^{-1}$ of $\mathrm{NO}_{2}^{-}-\mathrm{N}$, respectively (Fig 1d) with higher values detected from days 229 to 233 in the effluent, probably indicating a disturbance in nitrite to nitrate conversion (nitrite oxidizing bacteria metabolism) due to the re-introduction of diclofenac feeding. From day 236 until the end of the SBR operation, nitrite concentration, both in aeration phase and the treated effluent, was very low $(0.59$ $\mathrm{mg} \mathrm{L}^{-1}$ of $\mathrm{NO}_{2}{ }^{-} \mathrm{N}$ ), indicating a recovery in nitrite oxidizing bacteria metabolism. As seen in Fig 1e, from day 229 until the end of the bioreactor operation, the amount of nitrate in the effluent (up to $37.8 \mathrm{mg} \mathrm{L}^{-1}$ of $\mathrm{NO}_{3}{ }^{-}-\mathrm{N}$ ) was concomitant with removal of ammonia. Fig $2 \mathrm{~b}$ shows $\left[\mathrm{NH}_{4}{ }^{-}-\mathrm{N}\right],\left[\mathrm{NO}_{2}{ }^{-} \mathrm{N}\right]$ and $\left[\mathrm{NO}_{3}{ }^{-} \mathrm{N}\right]$ (all in $\mathrm{m} \mathrm{L}^{-1}$ ) concentration profiles, representing a typical cycle with diclofenac (from day 194 until day 233) and a cycle after diclofenac feeding stopped (from days 236 until the end of AGS-SBR operation). Although some studies report the sensibility of the nitrifying bacteria towards toxic compounds, such as chiral pharmaceuticals, fluoxetine and tetracycline $[15,31,32]$, in the current study ammonia oxidizing bacteria were not affected and nitrite oxidizing bacteria demonstrated its ability of adaptation to the micropollutant.

\subsubsection{Fate of diclofenac,}

The AGS bioreactor was not able to significantly reduce the diclofenac concentration. The DCF concentration used is higher than that normally found in wastewaters [7,9], but in the same range of those used in other studies on the removal of this pharmaceutical [33]. This concentration was chosen to promote a selective pressure that would favor the persistence of the degrading strain and of a microbial community adapted to the presence of the pharmaceutical within the bioaugmented granules. In Fig 3, diclofenac $\left(\mathrm{mg} \mathrm{L}^{-1}\right)$ concentration profile along an AGS-SBR cycle (Phase V) is shown. During each cycle ca $15 \%$ of the compound was retained with AGS, possibly through adsorption to the granules (Fig. 3), indeed in subsequent cycles without diclofenac feeding desorption accounted for all diclofenac fed into the bioreactor. Adorption/desorption mechanism onto AGS has been reported for pharmaceutical compounds, namely fluoroquinolones [34], although with those compounds adsorption was stronger. 
Fluoroquinolones were also evaluated in an AGS-SBR by Amorim et al. [13], where the compounds were firstly adsorbed to the AGS, and subsequently released to the medium in the following cycles. In the present study, diclofenac followed an adorption/desorption mechanism onto AGS, which prevailed over potential biodegradation. Labrys portucalensis F11 is a strictly aerobic bacterium, and it may be that the long anaerobic feeding process may slow down its metabolism. Although strain Labrys portucalensis F11 is able to degrade diclofenac as a sole carbon source, degradation is enhanced in the presence of acetate [23]. In the reactor, all acetate was consumed during the anaerobic phase which may have further limited the activity of Labrys portucalensis F11 preventing cometabolic degradation of diclofenac. The aeration time in each cycle was not sufficient for significant degradation of the pharmaceutical compound. In a previous report was showed that an AGS reactor bioaugmented with a 2-fluorophenol degrading strain was successful to degrade the contaminant [12]. That strain does not rely on co-metabolism and likely this difference is the main reason for the observed differences. The inefficiency in the diclofenac removal on SBR is in accordance with the results obtained by He et al. [35], in which it was observed a removal of $11.7 \%$ of $1 \mu \mathrm{g} \mathrm{L}^{-1}$ in a SBR seeded with activated sludge. On the other hand, removal of diclofenac $(1 \mathrm{mg}$ $\mathrm{L}^{-1}$ ) was achieved by fungal granules but with a cycle length of 1 day and in co-metabolism with $10 \mathrm{~g} \mathrm{~L}^{-1}$ of glucose [36]. Diclofenac removal efficiencies of $65 \%$ and $55 \%$ were observed in respirometric assays using activated sludge with 1 and $10 \mu \mathrm{g} / \mathrm{L}$ of diclofenac, respectively, and dominance of heterotrophic biomass on the removal [37].

Over the past years, several researchers assessed the ability of different bioreactors for diclofenac degradation. Nguyen et al. [38] evaluated the removal of diclofenac using a membrane bioreactor, resulting in 4-26\% removal; the addition of granular activated carbon (GAC) improved the removal to 96\% through adsorption onto GAC. A moving bed biofilm reactor (MBBR) was used for the removal of pharmaceuticals from wastewater [39]. The reactor itself accounted for $74-85 \%$ of diclofenac removal. When the MBBR was coupled with hydrodynamic cavitation/hydrogen peroxide process and UV treatment, diclofenac removal increased to $98 \%$ [39]. Another study explored the use of aerated biofilters with manganese feeding, which resulted in an efficient diclofenac removal, but with a long adaptation time (ca. 1 year) [40]. Lonappan and co-workers [33] investigated the removal of diclofenac through adsorption onto micro-biochar fixed bed column with ca. $70 \%$ of removal achieved. The abovementioned studies report diclofenac removal mainly through adsorption and not through biodegradation. In fact, diclofenac removal through adsorption has been reported in several studies, using activated 
carbon [41,42], graphene oxide nanosheets [43], composite low-cost material [44] and biphasic apatitecarbon biochar-type materials prepared from pyrolysed cod fish bones [45]. Further combined strategies are needed to effectively remove pharmaceuticals such as diclofenac from wastewater.

\subsection{Granular biomass properties}

The bed volume and TSS were measured during the different operational conditions applied to the bioreactor as shown in Fig. 4. High values of TSS in the effluent were observed during phase II, corresponding to the granulation period, in which settling times were gradually decreased. As the settling time remained at $3 \mathrm{~min}$, only particles with a settling velocity larger than $6 \mathrm{~m} \mathrm{~h}^{-1}$ were effectively retained in the reactor, concomitantly TSS showed a substantial decrease $\left(0.56 \mathrm{~g} \mathrm{~L}^{-1}\right)$, maintaining average values of $0.17 \mathrm{~g} \mathrm{~L}^{-1}$ until the end of the reactor operation. By the end of stage II, mature and stable granules were observed (Fig 5). From previous studies, granulation process usually takes ca. 1 month [46]. In the current study, granulation period was longer probably due to the constant presence of diclofenac. Diclofenac may exhibit inhibitory effects on bacterial communities, mainly due to its ability to inhibit DNA synthesis [47]. The selective pressure imposed by diclofenac on the seed sludge during the acclimatization period aimed at maintaining the metabolism of the degrading strain and at the same time to select for a microbial community that was able to proliferate in the presence of the compound. Acclimatization strategies were found to be positive in previous studies on the degradation of toxic compounds by AGS $[16-19,48]$. That strategy was kept during phase II in order to evaluate the effect of diclofenac on the granulation process. Albeit a longer granulation period was required, stable and mature granules were obtained under the imposed selective pressure.

The bed volume remained constant during phases II, III and VI (19 $\mathrm{cm}$ in average). In Phases IV and V, a decrease was observed corresponding to periods of diclofenac intermittent feeding. Table 2 summarizes $\checkmark$

the physical characteristics of AGS during reactor operation. At the beginning of SBR operation (Phase II) MLVSS was in average $3.0 \mathrm{~g} \mathrm{~L}^{-1}$, with an increase when diclofenac was removed from the feeding (Phase III) with a concomitant increase of the SRT. When feeding with diclofenac returned (Phase IV), the biomass concentration decreased drastically $\left(2.7 \mathrm{~g} \mathrm{~L}^{-1}\right)$, decreasing even further on Phase V $\left(0.75 \mathrm{~g} \mathrm{~L}^{-}\right.$ ${ }^{1}$ ), accompanied by a decrease of the SRT. After diclofenac feeding stopped (Phase VI) an increase occurred $\left(1.4 \mathrm{~g} \mathrm{~L}^{-1}\right)$, but not reaching the initial values. The activity of biomass (represented by the ratio 
between MLVSS and MLSS) suffered a slight decrease from Phases IV to V. $\mathrm{SVI}_{5}$ demonstrated an increasing trend along bioreactor operation, strengthening AGS compressibility and settleability.

A high biomass concentration was observed along the first phases of the reactor operation, with the lowest biomass concentration being recorded when an increase in aeration phase occurred, leading to an increase in turbulence inside the reactor which may lead to breaking of the granules causing biomass losses during effluent washout. Similar results were observed previously [15]. Nevertheless, biomass activity remained constant throughout the whole experiment, even during diclofenac exposure or longer aeration times, indicating that the presence of active biomass in the biorreactor was maintained. A decline in AGS settling properties was observed when longer aeration times were settled with an upward trend in $\mathrm{SVI}_{5}$. Similar results were observed in previous reports dealing with chiral pharmaceuticals [31].

\subsection{Bacterial community of the AGS-SBR}

\subsubsection{Capacity of bacterial isolates recovered from the AGS to degrade diclofenac}

From phases III and VI bacterial strains able to degrade diclofenac were isolated and identified (Table 3).

A total of eleven bacterial isolates were retrieved from agar plates containing diclofenac, with three strains affiliated with $\alpha$-Proteobacteria, two with $\beta$-Proteobacteria, three with $\gamma$-Proteobacteria, two with Actinobacteria and one with Bacteroidetes. The majority of the culturable isolates were from the Proteobacteria group, which is in accordance with previous studies [49]. Most of the isolates were closely related to environmental samples (soil, river water, groundwater, coal) as well as wastewater treatment plants. Labrys portucalensis strain F11 was not recovered through this approach. The capacity of each isolate to use diclofenac $\left(9.54 \mathrm{mg} \mathrm{L}^{-1}\right)$ as a sole carbon source was tested in liquid batch mode for 30 days. Their degradation ability (in percentage) is presented in Table 3 . The highest degradation obtained was $33.5 \%$, that was about half of the extent achieved by Labrys portucalensis F11 for the same diclofenac concentration supplied as a sole carbon source [23]. No decrease in diclofenac concentration was registered in control assays (data not shown), demonstrating that neither adsorption nor abiotic degradation occurred under the tested conditions.

\subsubsection{Molecular analysis of bacterial communities of the AGS-SBR}


The variations in the bacterial community in AGS, collected along the SBR operation, were investigated by DGGE of $16 \mathrm{~S}$ rRNA gene (Fig. 6). The DGGE patterns showed a dynamic bacterial microbial community during bioreactor operation. A total of 176 distinct bands were retrieved, with the number of DGGE bands per lane varied between 13 and 22, indicating a wide bacterial diversity within the granules. One band was present in every sample (band b3) while others were only present in specific sampling days (bands b1, b2, b8 and b20) (Fig. 6).

A cluster analysis (Fig. 7) showed that the bacterial assemblages present two main branches separating the samples from the phases I and II from those taken from phases III - VI. The first branch clearly shows the sludge acclimatization to diclofenac and the granulation phase with samples collected from days 0 and 20 (during acclimatization process) showing less than $30 \%$ of similarity. When the operation mode was changed from bubble column to SBR mode (day 20) a slightly change in the microbial community was observed as the similarities between day 20 and 26 were $75 \%$. A more pronounced effect was observed during the granules formation (phase II), between days 26 and 40 (less than 30\% similarity) and between days 40 and 68 (ca. 55\% similarity), indicating a re-structuring of the community imposed by the decreasing settling time and the concomitant granule formation and that the formed matured granules were constituted by an adapted microbial population. The second branch can be sub-divided in two: one that combines days 110 and 142, representing phase III, where no diclofenac was being loaded to the bioreactor, and the second sub-branch including phases V and VI. Dynamic microbial community of AGS-SBR with major shift attributed to continuous feeding with pharmaceuticals was reported by Amorim et al. [50].

Numerical analysis of DGGE profiles (Fig. 7) showed that the Shannon's diversity index (H) varied between 0.70 and 1.22. A higher species abundance and diversity $(\mathrm{H})$ were obtained on phase III when diclofenac was not fed into the reactor, probably indicating that some species in the granules were inhibited when diclofenac was present. The Equitability index (E) varied between 0.60 and 0.94 (days 286 and 26 , respectively), indicating an increase in dominance of some species by the end of the experiment. The lowest $\mathrm{H}$ and $\mathrm{E}$ values were obtained on the last experimental day, suggesting a low species diversity but with a high dominance, even after diclofenac has being removed from the inlet 30 days before, reinforcing the pressure exerted from this micropollutant on microbial communities.

Selected DGGE bands (Fig. 6) were excised for direct PCR amplification followed by DNA sequencing. Partial 16S rRNA gene sequences were successfully obtained from twenty-one DGGE bands (b1 - b21 in 
Fig. 6) and compared with nucleotide sequences from GenBank (Table 4). According to its presence along the reactor operation, the most predominant phyla was Proteobacteria (subclasses $\beta>\alpha \approx \gamma$ ) and uncultured organisms followed by Bacteroidetes and Firmicutes, obtained from environmental samples, such as sediments, but also from treatment plants and even drinking water, which is in accordance with previous reports on aerobic granules microbial population [51]. Thauera sp. (accession $\mathrm{n}^{\mathrm{o}}$ LC145286 and $\mathrm{n}^{\circ}$ MH665743) was present in all samples from the granule formation phase (phase II). It is known that the genus Thauera $s p$. is involved in microbial aggregation and granule stability as they are able to produce exopolysaccharides (EPS) which strengths the microbial core [52]. Its presence during phase III can be related to its ability to remove organic compounds, such as acetate, as previously demonstrated by Liu et al., [54]. Bands 3, 11 and 29 presented a high similarity (99\%) with the degrading strain Labrys portucalensis F11 and its presence was maintained throughout the entire reactor operation (on Table 4, bands 3, 11 and 21). This is an evidence of the success of the bioaugmentation strategy adopted for the incorporation of the selected strain into the granules.

\subsubsection{Capacity of AGS to degrade diclofenac in batch mode}

Batch liquid cultures containing aerobic granules and $0.03 \mathrm{mM}$ of diclofenac were established to investigate their diclofenac biodegradation ability. At the same time, adsorption assays were conducted. The diclofenac removal achieved is presented in Fig. 8. During the first 9 days, diclofenac concentration decreased very slowly in biodegradation assays, however after the second feeding with acetate (day 14), the degradation increased, The DCF degradation rate constant $\left(0.042 \pm 0.0006 \mathrm{~d}^{-1}\right)$ was well fitted to the first-order kinetics (the value of $\mathrm{R}^{2}=0.96$ ). By the end of the experiment, $72 \%$ of the diclofenac fed was removed, indicating the ability of AGS to degrade the pharmaceutical compound in cometabolism with acetate (Fig. 8). On control assays with inactivated granules (Fig. 8), some adsorption of diclofenac onto granules was observed during the first 10 days, after which desorption started to occur, reaching the initial $\checkmark$ diclofenac concentration in the liquid by the end of the experiment. No granules disintegration was observed during the experimental period. Also, no decrease in DCF concentration was observed in biotic and abiotic control assays. The granules from the reactor showed the ability to degrade diclofenac at higher degradation rates than the culturable isolated strains, reinforcing the contribution of the bioaugmented Labrys portucalensis F11 for the obtained results. 


\section{Conclusions}

In the present study, introduction of diclofenac for a long period in the feeding of an established AGSSBR bioaugmented with a strain able to biodegrade the target micropollutant did not cause a negative impact on its main biological functions. COD, phosphate and ammonia removal were not affected by the presence of the diclofenac, demonstrating the robustness facing the presence of micropollutants. Nitrite oxidizing bacteria demonstrated its ability of adaptation to the micropollutant and recover activity. A dynamic microbial community during AGS-SBR operation was observed. Bioaugmentation with a strain able to biodegrade diclofenac was successful from the point of view of establishing specialized granules within AGS reactor, even though the short length of reaction time imposed by the cycle duration did not allow for the removal of the pharmaceutical compound.

\section{Acknowledgements}

V.S. Bessa wish to acknowledge research grant from Fundação para a Ciência e Tecnologia (FCT), Portugal (Ref. SFRH/BD/90146/2012) and Fundo Social Europeu (Programa Operacional Potencial Humano (POPH), Quadro de Referência Estratégico Nacional (QREN)). This work was supported by National Funds from FCT - Fundação para a Ciência e a Tecnologia - through the project AGeNT PTDC/BTA-BTA/ 31264/2017 (POCI-01-0145-FEDER-031264). We would also like to thank the scientific collaboration of CBQF under the FCT project UID/Multi/50016/2019.

\section{References}

[1] M.J. Bernot, J.C. Becker, J. Doll, T.E. Lauer, A national reconnaissance of trace organic compounds (TOCs) in United States lotic ecosystems, Sci. Total Environ. 572 (2016) 422-433. doi:10.1016/j.scitotenv.2016.08.060.

[2] S.D. Richardson, S.Y. Kimura, Emerging environmental contaminants: Challenges facing our next generation and potential engineering solutions, Environ. Technol. Innov. 8 (2017) 40-56. doi:10.1016/j.eti.2017.04.002.

[3] Y. Yang, Y.S. Ok, K.-H. Kim, E.E. Kwon, Y.F. Tsang, Occurrences and removal of pharmaceuticals and personal care products (PPCPs) in drinking water and water/sewage 
treatment plants: A review, Sci. Total Environ. 596-597 (2017) 303-320.

doi:10.1016/j.scitotenv.2017.04.102.

[4] X. Liu, C. Liang, X. Liu, F. Zhao, C. Han, Occurrence and human health risk assessment of pharmaceuticals and personal care products in real agricultural systems with long-term reclaimed wastewater irrigation in Beijing, China, Ecotoxicol. Environ. Saf. 190 (2020) 110022. doi:10.1016/j.ecoenv.2019.110022.

[5] R.P. Bisognin, D.B. Wolff, E. Carissimi, O.D. Prestes, R. Zanella, Occurrence and fate of pharmaceuticals in effluent and sludge from a wastewater treatment plant in Brazil, Environ. Technol. (United Kingdom). 0 (2019) 1-12. doi:10.1080/09593330.2019.1701561.

[6] EU Decision 2018/840, Commission Implementing Decision (EU) 2018/840 of 5 June 2018, Off. J. Eur. Union. 141 (2018) 9-12.

[7] N. Vieno, M. Sillanpää, Fate of diclofenac in municipal wastewater treatment plant - A review, Environ. Int. 69 (2014) 28-39. doi:10.1016/j.envint.2014.03.021.

[8] S. Aydin, M.E. Aydin, A. Ulvi, Monitoring the release of anti-inflammatory and analgesic pharmaceuticals in the receiving environment, Environ. Sci. Pollut. Res. 26 (2019) 36887-36902. doi:10.1007/s11356-019-06821-4.

[9] S. Afsa, K. Hamden, P.A. Lara Martin, H. Ben Mansour, Occurrence of 40 pharmaceutically active compounds in hospital and urban wastewaters and their contribution to Mahdia coastal seawater contamination, Environ. Sci. Pollut. Res. 27 (2020) 1941-1955. doi:10.1007/s11356019-06866-5.

[10] S. Bengtsson, M. de Blois, B.M. Wilén, D. Gustavsson, A comparison of aerobic granular sludge with conventional and compact biological treatment technologies, Environ. Technol. (United Kingdom). 40 (2019) 2769-2778. doi:10.1080/09593330.2018.1452985.

[11] S.S. Adav, D.-J. Lee, J.-Y. Lai, Treating chemical industries influent using aerobic granular sludge: Recent development, J. Taiwan Inst. Chem. Eng. 40 (2009) 333-336. doi:10.1016/j.jtice.2009.02.002. 
[12] A.F. Duque, V.S. Bessa, M.F. Carvalho, M.K. de Kreuk, M.C.M. van Loosdrecht, P.M.L. Castro, 2-Fluorophenol Degradation By Aerobic Granular Sludge in a Sequencing Batch Reactor., Water Res. 45 (2011) 6745-52. doi:10.1016/j.watres.2011.10.033.

[13] C.L. Amorim, A.S. Maia, R.B.R. Mesquita, A.O.S.S. Rangel, M.C.M. van Loosdrecht, M.E. Tiritan, et al., Performance of aerobic granular sludge in a sequencing batch bioreactor exposed to ofloxacin, norfloxacin and ciprofloxacin., Water Res. 50 (2014) 101-13. doi:10.1016/j.watres.2013.10.043.

[14] J. Kent, J.H. Tay, Treatment of $17 \alpha$ - ethinylestradiol, 4- nonylphenol, and carbamazepine in wastewater using an aerobic granular sludge sequencing batch reactor, Sci. Total Environ. 652 (2019) 1270-1278. doi:10.1016/j.scitotenv.2018.10.301.

[15] I.S. Moreira, C.L. Amorim, A.R. Ribeiro, R.B.R. Mesquita, A.O.S.S. Rangel, M.C.M. Van Loosdrecht, et al., Removal of fluoxetine and its effects in the performance of an aerobic granular sludge sequential batch reactor, J. Hazard. Mater. 287(2015) 93-101. doi:10.1016/j.jhazmat.2015.01.020.

[16] M.Z. khan, P.K. Mondal, S. Sabir, Bioremediation of 2-chlorophenol containing wastewater by aerobic granules-kinetics and toxicity, J. Hazard. Mater. 190 (2011) 222-228. doi:10.1016/j.jhazmat.2011.03.029.

[17] H. Jiang, J. Tay, A.M. Maszenan, S.T. Tay, Bacterial Diversity and Function of Aerobic Granules Engineered in a Sequencing Batch Reactor for Phenol Degradation Bacterial Diversity and Function of Aerobic Granules Engineered in a Sequencing Batch Reactor for Phenol Degradation, (2004). doi:10.1128/AEM.70.11.6767.

[18] M.Z. khan, P.K. Mondal, S. Sabir, V. Tare, Degradation pathway, toxicity and kinetics of 2,4,6trichlorophenol with different co-substrate by aerobic granules in SBR, Bioresour. Technol. 102 (2011) 7016-7021. doi:10.1016/j.biortech.2011.04.057.

[19] S.G. Wang, X.W. Liu, H.Y. Zhang, W.X. Gong, X.F. Sun, B.Y. Gao, Aerobic granulation for 2,4-dichlorophenol biodegradation in a sequencing batch reactor, Chemosphere. 69 (2007) 769775. doi:10.1016/j.chemosphere.2007.05.026. 
[20] S. Yi, W.Q. Zhuang, B. Wu, S.T.L. Tay, J.H. Tay, Biodegradation of p-nitrophenol by aerobic granules in a sequencing batch reactor, Environ. Sci. Technol. 40 (2006) 2396-2401. doi:10.1021/es0517771.

[21] J. yun Ma, X. chun Quan, Z. feng Yang, A. jie Li, Biodegradation of a mixture of 2,4dichlorophenoxyacetic acid and multiple chlorophenols by aerobic granules cultivated through plasmid pJP4 mediated bioaugmentation, Chem. Eng. J. 181-182 (2012) 144-151. doi:10.1016/j.cej.2011.11.041.

[22] F.B. Yu, S.W. Ali, L.B. Guan, S.P. Li, S. Zhou, Bioaugmentation of a sequencing batch reactor with Pseudomonas putida ONBA-17, and its impact on reactor bacterial communities, J. Hazard. Mater. 176 (2010) 20-26. doi:10.1016/j.jhazmat.2009.06.006.

[23] I.S. Moreira, V.S. Bessa, S. Murgolo, C. Piccirillo, G. Mascolo, P.M.L. Castro, Biodegradation of Diclofenac by the bacterial strain Labrys portucalensis F11, Ecotoxicol. Environ. Saf. 152 (2018) 104-113. doi:10.1016/j.ecoenv.2018.01.040.

[24] I.S. Moreira, C.L. Amorim, M.F. Carvalho, A.C. Ferreira, C.M. Afonso, P.M.L. Castro, Effect of the metals iron, copper and silver on fluorobenzene biodegradation by Labrys portucalensis, Biodegradation. 24 (2013) 245-255. doi:10.1007/s10532-012-9581-6.

[25] M. Pronk, J.P. Bassin, M.K. de Kreuk, R. Kleerebezem, M.C.M. van Loosdrecht, Evaluating the main and side effects of high salinity on aerobic granular sludge., Appl. Microbiol. Biotechnol. 98 (2014) 1339-48. doi:10.1007/s00253-013-4912-z.

[26] APHA, Standard Methods for the Examination of Water and Wastewater, Twentieth, American Public Health Association/American Water Works Association/Water Environment Federation, Washington, DC., USA., 1998. doi:ISBN 9780875532356.

[27] V.S. Bessa, I.S. Moreira, M.E. Tiritan, P.M.L. Castro, Enrichment of bacterial strains for the biodegradation of diclofenac and carbamazepine from activated sludge, Int. Biodeterior.

Biodegrad. 120 (2017). doi:10.1016/j.ibiod.2017.02.008.

[28] C.E. Shannon; W. Weaver, The Mathematical Theory of Communication, The University of 
Illinois Press, Urbana, IL, 1963.

[29] C.L. Amorim, I.S. Moreira, A.R. Ribeiro, L.H.M.L.M. Santos, C. Delerue-Matos, M.E. Tiritan, et al., Treatment of a simulated wastewater amended with a chiral pharmaceuticals mixture by an aerobic granular sludge sequencing batch reactor, Int. Biodeterior. Biodegrad. 115 (2016). doi:10.1016/j.ibiod.2016.09.009.

[30] M.K. de Kreuk, J.J. Heijnen, M.C.M. van Loosdrecht, Simultaneous COD, nitrogen, and phosphate removal by aerobic granular sludge., Biotechnol. Bioeng. 90 (2005) 761-9. doi:10.1002/bit.20470.

[31] C.L. Amorim, I.S. Moreira, A.R. Ribeiro, L.H.M.L.M. Santos, C. Delerue-Matos, M.E. Tiritan, et al., Treatment of a simulated wastewater amended with a chiral pharmaceuticals mixture by an aerobic granular sludge sequencing batch reactor, Int. Biodeterior. Biodegrad. 115 (2016) 277285. doi:10.1016/j.ibiod.2016.09.009.

[32] Y. Shi, S. Xing, X. Wang, S. Wang, Bioresource Technology Changes of the reactor performance and the properties of granular sludge under tetracycline ( TC ) stress, Bioresour. Technol. 139 (2013) 170-175. doi:10.1016/j.biortech.2013.03.037.

[33] L. Lonappan, T. Rouissi, Y. Liu, S.K. Brar, R. Y. Surampalli, Removal of diclofenac using microbiochar fixed-bed column bioreactor, J. Environ. Chem. Eng. 7 (2019) 102894. doi:10.1016/j.jece. 2019.102894.

[34] V.R.A. Ferreira, C.L. Amorim, S.M. Cravo, M.E. Tiritan, P.M.L. Castro, C.M.M. Afonso, Fluoroquinolones biosorption onto microbial biomass: Activated sludge and aerobic granular sludge, Int. Biodeterior. Biodegrad. 110 (2016) 53-60. doi:10.1016/j.ibiod.2016.02.014.

[35] K. He, Y. Asada, S. Echigo, S. Itoh, Biodegradation of pharmaceuticals and personal care products in the sequential combination of activated sludge treatment and soil aquifer treatment, Environ. Technol. (United Kingdom). 41 (2020) 378-388. doi:10.1080/09593330.2018.1499810.

[36] T.K. Kasonga, M.A.A. Coetzee, I. Kamika, M.N.B. Momba, Assessing a co-culture fungal granule ability to remove pharmaceuticals in a sequencing batch reactor, Environ. Technol. 
(United Kingdom). 0 (2020) 1-16. doi:10.1080/09593330.2020.1847204.

[37] B. Ciftcioglu, E. Demirkaya, E. Salih, D. Soylu, G. Ozyildiz, G.E. Zengin, et al., Insights into the acute effect of anti-inflammatory drugs on activated sludge systems with high solids retention time, Environ. Technol. (United Kingdom). 0 (2020) 1-12. doi:10.1080/09593330.2020.1761456.

[38] L.N. Nguyen, F.I. Hai, J. Kang, W.E. Price, L.D. Nghiem, Removal of trace organic contaminants by a membrane bioreactor-granular activated carbon (MBR-GAC) system, Bioresour. Technol. 113 (2012) 169-173. doi:10.1016/j.biortech.2011.10.051.

[39] M. Zupanc, T. Kosjek, M. Petkovšek, M. Dular, B. Kompare, B. Širok, et al., Removal of pharmaceuticals from wastewater by biological processes, hydrodynamic cavitation and UV treatment, Ultrason. Sonochem. 20 (2013) 1104-1112. doi:10.1016/j.ultsonch.2012.12.003.

[40] Y. Zhang, H. Zhu, U. Szewzyk, S.U. Geissen, Removal of pharmaceuticals in aerated biofilters with manganese feeding, Water Res. 72 (2015) 218-226. doi:10.1016/j.watres.2015.01.009.

[41] A. Gil, N. Taoufik, A.M. García, S.A. Korili, Comparative removal of emerging contaminants from aqueous solution by adsorption on an activated carbon, Environ. Technol. (United Kingdom). 40 (2019) 3017-3030. doi:10.1080/09593330.2018.1464066.

[42] H. Fallou, S. Giraudet, N. Cimetière, D. Wolbert, P. Le Cloirec, Adsorption onto ACFC of mixture of pharmaceutical residues in water-experimental studies and modelling, Environ. Technol. (United Kingdom). 0 (2020) 1-11. doi:10.1080/09593330.2020.1716393.

[43] A.C.S. Guerra, M.B. de Andrade, T.R. Tonial dos Santos, R. Bergamasco, Adsorption of sodium diclofenac in aqueous medium using graphene oxide nanosheets, Environ. Technol. (United Kingdom). 0 (2019) 1-11. doi:10.1080/09593330.2019.1707882.

[44] G.R. Salomão, J.H.P. Américo-Pinheiro, W.D. Isique, N.H. Torres, I.A. Cruz, L.F.R. Ferreira, Diclofenac removal in water supply by adsorption on composite low-cost material, Environ. Technol. (United Kingdom). 0 (2019) 1-17. doi:10.1080/09593330.2019.1692078.

[45] C. Piccirillo, I.S. Moreira, R.M. Novais, A.J.S. Fernandes, R.C. Pullar, P.M.L. Castro, Biphasic apatite-carbon materials derived from pyrolysed fish bones for effective adsorption of persistent 
pollutants and heavy metals, J. Environ. Chem. Eng. 5 (2017). doi:10.1016/j.jece.2017.09.010.

[46] M.K. de Kreuk, M. Pronk, M.C.M. van Loosdrecht, Formation of aerobic granules and conversion processes in an aerobic granular sludge reactor at moderate and low temperatures., Water Res. 39 (2005) 4476-84. doi:10.1016/j.watres.2005.08.031.

[47] S.G. Dastidar, K. Ganguly, K. Chaudhuri, A.N. Chakrabarty, The anti-bacterial action of diclofenac shown by inhibition of DNA synthesis, Int. J. Antimicrob. Agents. 14 (2000) 249-251. doi:10.1016/S0924-8579(99)00159-4.

[48] S. Yi, W.-Q. Zhuang, B. Wu, S.T.-L. Tay, J.-H. Tay, Biodegradation of $\mathrm{p}$-Nitrophenol by Aerobic Granules in a Sequencing Batch Reactor, Environ. Sci. Technol. 40 (2006) 2396-2401. doi:10.1021/es0517771.

[49] H.L. Jiang, J.H. Tay, A.M. Maszenan, S.T.L. Tay, Bacterial diversity and function of aerobic granules engineered in a sequencing batch reactor for phenol degradation, Appl. Environ. Microbiol. 70 (2004) 6767-6775. doi:10.1128/AEM.70.11.6767.

[50] C.L. Amorim, M. Alves, P.M.L. Castro, I. Henriques, Bacterial community dynamics within an aerobic granular sludge reactor treating wastewater loaded with pharmaceuticals, Ecotoxicol. Environ. Saf. 147 (2018) 905-912. doi:10.1016/j.ecoenv.2017.09.060.

[51] M.K.H. Winkler, C. Meunier, O. Henriet, J. Mahillon, M.E. Suárez-Ojeda, G. Del Moro, et al., An integrative review of granular sludge for the biological removal of nutrients and recalcitrant organic matter from wastewater, Chem. Eng. J. 336 (2018) 489-502. doi:10.1016/j.cej.2017.12.026.

[52] M.S. Allen, K.T. Welch, B.S. Prebyl, D.C. Baker, A.J. Meyers, G.S. Sayler, Analysis and glycosyl composition of the exopolysaccharide isolated from the floc-forming wastewater bacterium Thauera sp. MZ1T, Environ. Microbiol. 6 (2004) 780-790. doi:10.1111/j.14622920.2004.00615.x.

[53] B. Liu, F. Zhang, X. Feng, Y. Liu, X. Yan, X. Zhang, et al., ThaueraandAzoarcusasfunctionally importantgenera ina denitrifyingquinoline-removal bioreactorasrevealedby microbial 
communitystructure comparison, FEMS Microbiol. Ecol. 55 (2006) 274-286.

doi:10.1111/j.1574.6941.2005.00033.x.

[54] Y.-Q. Liu, J.-H. Tay, Variable aeration in sequencing batch reactor with aerobic granular sludge., J. Biotechnol. 124 (2006) 338-46. doi:10.1016/j.jbiotec.2005.12.037.
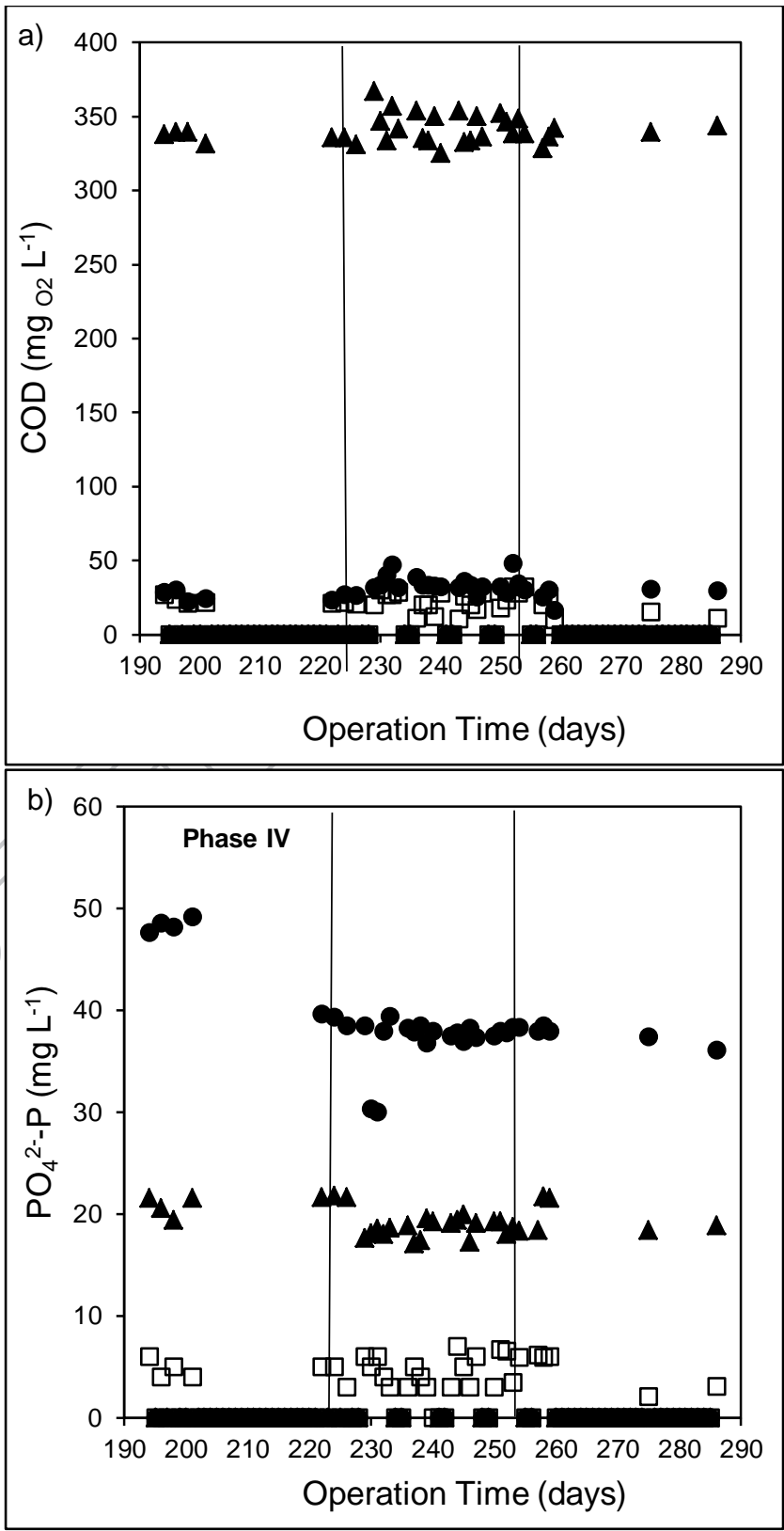

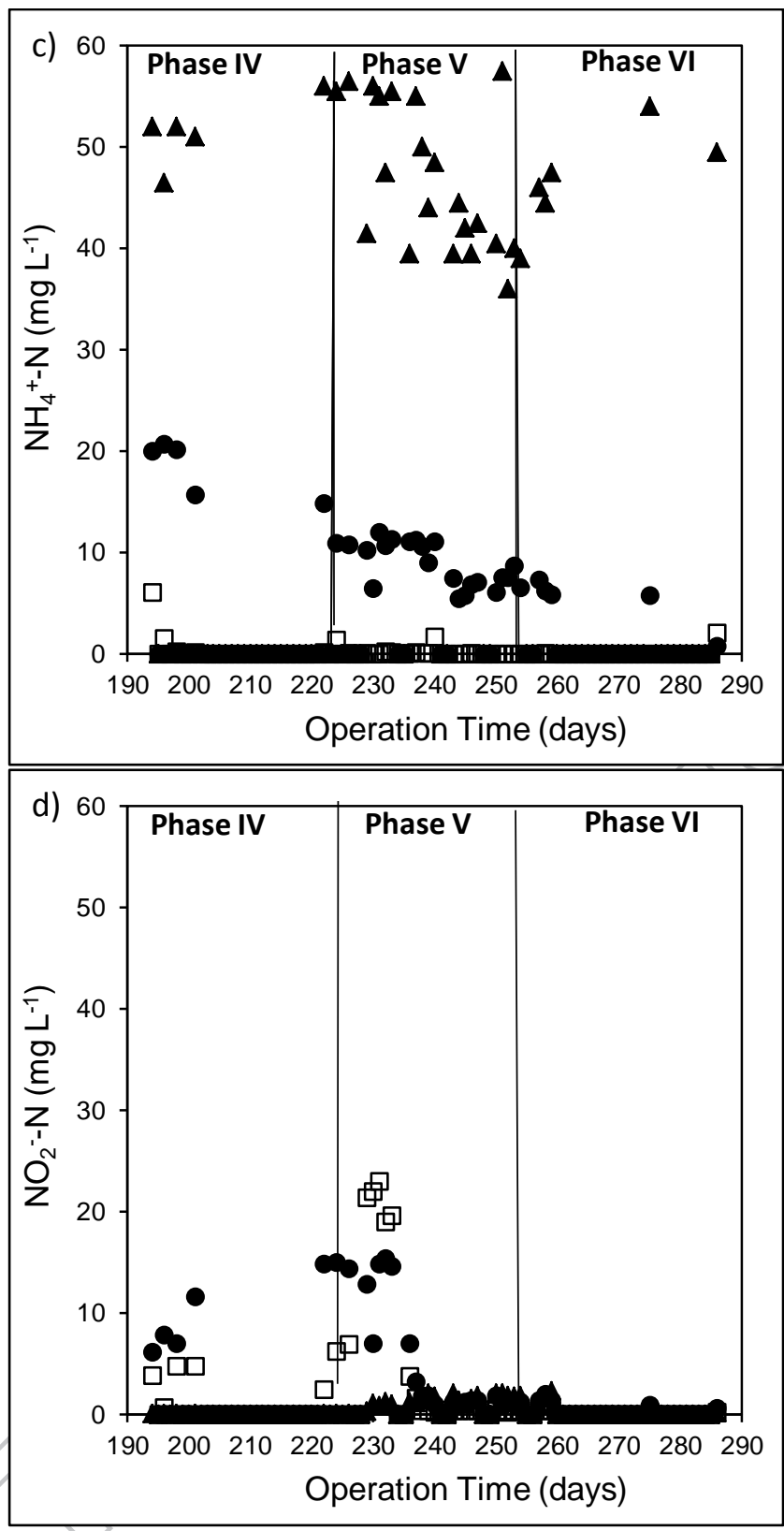


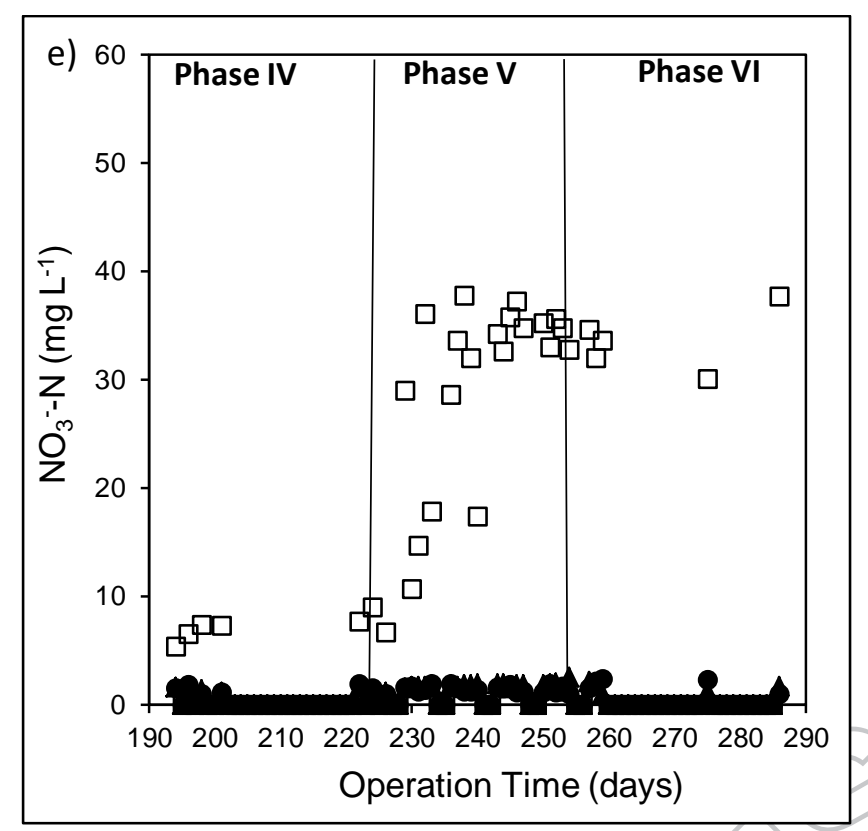

Fig. 1 (a) $\mathrm{COD}\left(\mathrm{mg}_{\mathrm{O} 2} \mathrm{~L}^{-1}\right)$, (b) $\left[\mathrm{PO}_{4}{ }_{4}^{2-}-\mathrm{P}\right]\left(\mathrm{mg} \mathrm{L}^{-1}\right)$, (c) $\left[\mathrm{NH}_{4}{ }^{+}-\mathrm{N}\right]\left(\mathrm{mg} \mathrm{L}^{-1}\right),(\mathrm{d})\left[\mathrm{NO}_{2}-\mathrm{N}\right]\left(\mathrm{mg} \mathrm{L}^{-1}\right)$ and (e) $\left[\mathrm{NO}_{3}^{-}-\mathrm{N}\right]\left(\mathrm{mg} \mathrm{L}^{-1}\right)$ concentration profiles during SBR operation. Concentrations in the Inlet $(\boldsymbol{\Lambda})$, one hour after feeding $(\bullet)$ and effluent $(\square)$ are presented.
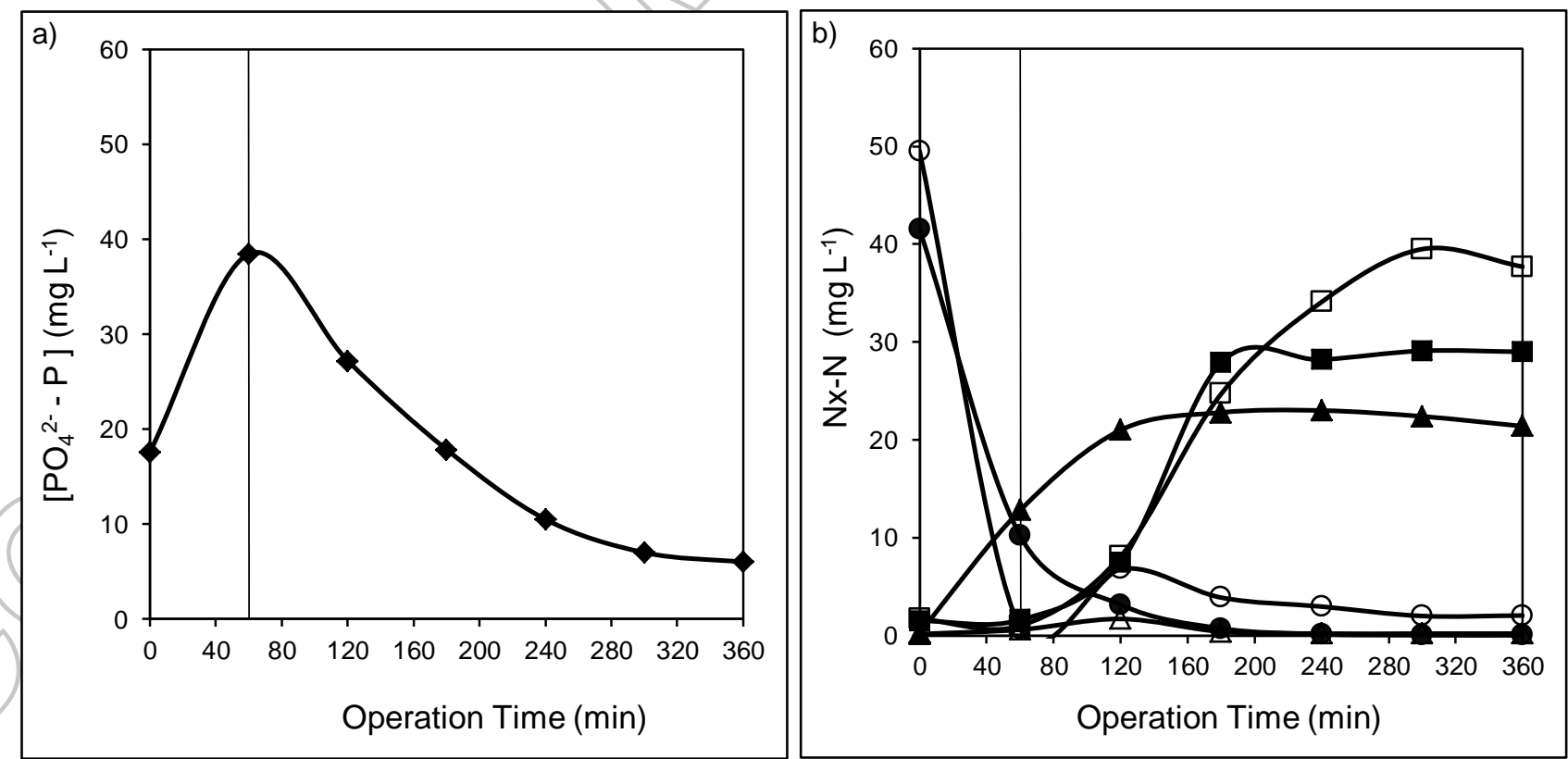
Fig. 2 (a) $\left[\mathrm{PO}_{4}{ }^{2-}-\mathrm{P}\right]\left(\mathrm{mg} \mathrm{L}^{-1}\right)\left(\right.$ diamonds) and (b) $\left[\mathrm{NH}_{4}{ }^{+}-\mathrm{N}\right]\left(\mathrm{mg} \mathrm{L}^{-1}\right)$ (circles), $\left[\mathrm{NO}_{2}{ }^{-}-\mathrm{N}\right]\left(\mathrm{mg} \mathrm{L}^{-1}\right)$ (triangles) and $\left[\mathrm{NO}_{3}{ }^{-} \mathrm{N}\right]\left(\mathrm{mg} \mathrm{L}^{-1}\right)$ (squares) profiles along AGS-SBR operation. Filled symbols represent a cycle with diclofenac feeding from day 194 until day 233 and empty symbols a cycle thereafter (from day 236 until the end of AGS-SBR operation).

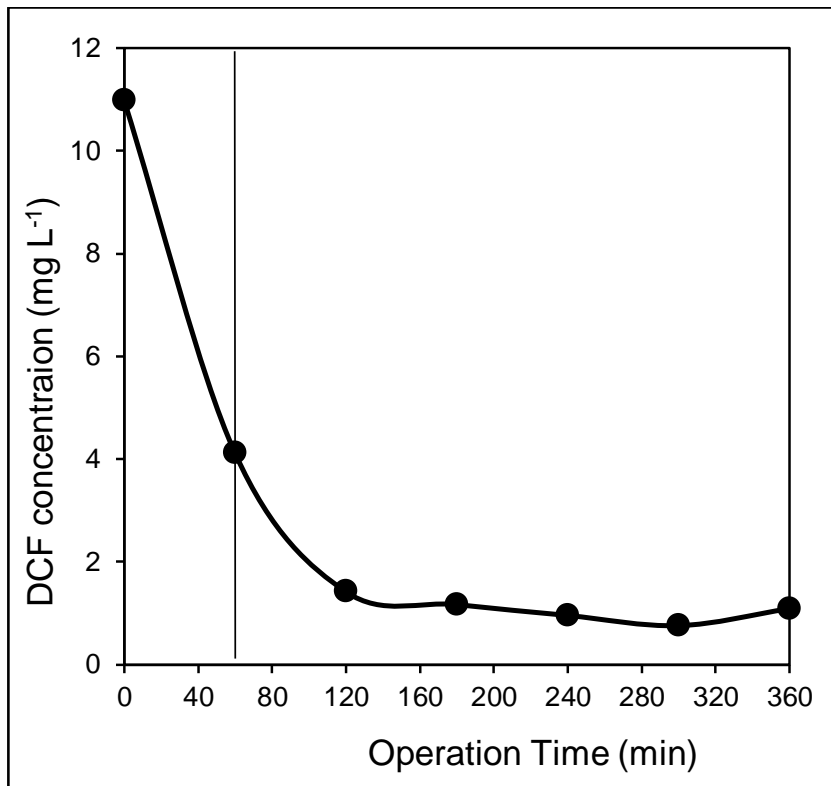

Fig. 3 Diclofenac concentration (mg L ${ }^{-1}$ ) profile along AGS-SBR operation (Phase V).

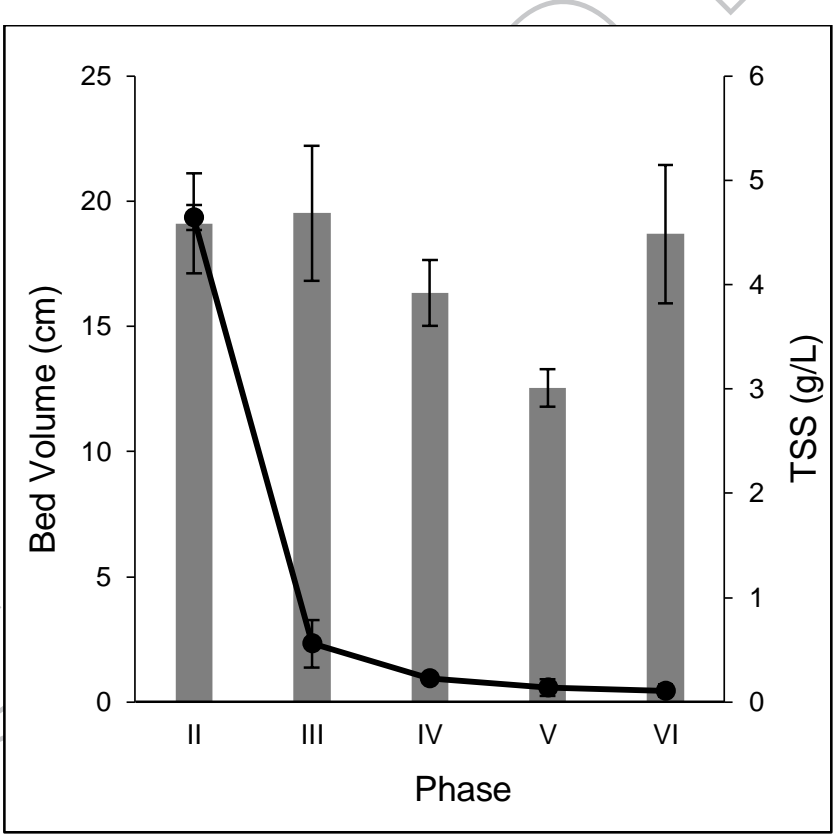

Fig. 4 Profile of the bed volume and TSS of the effluent during AGS-SBR operation. Columns represent the bed volume whereas data points represent TSS in the effluent $(\bullet)$. Values are means \pm standard error of the mean (SEM). 

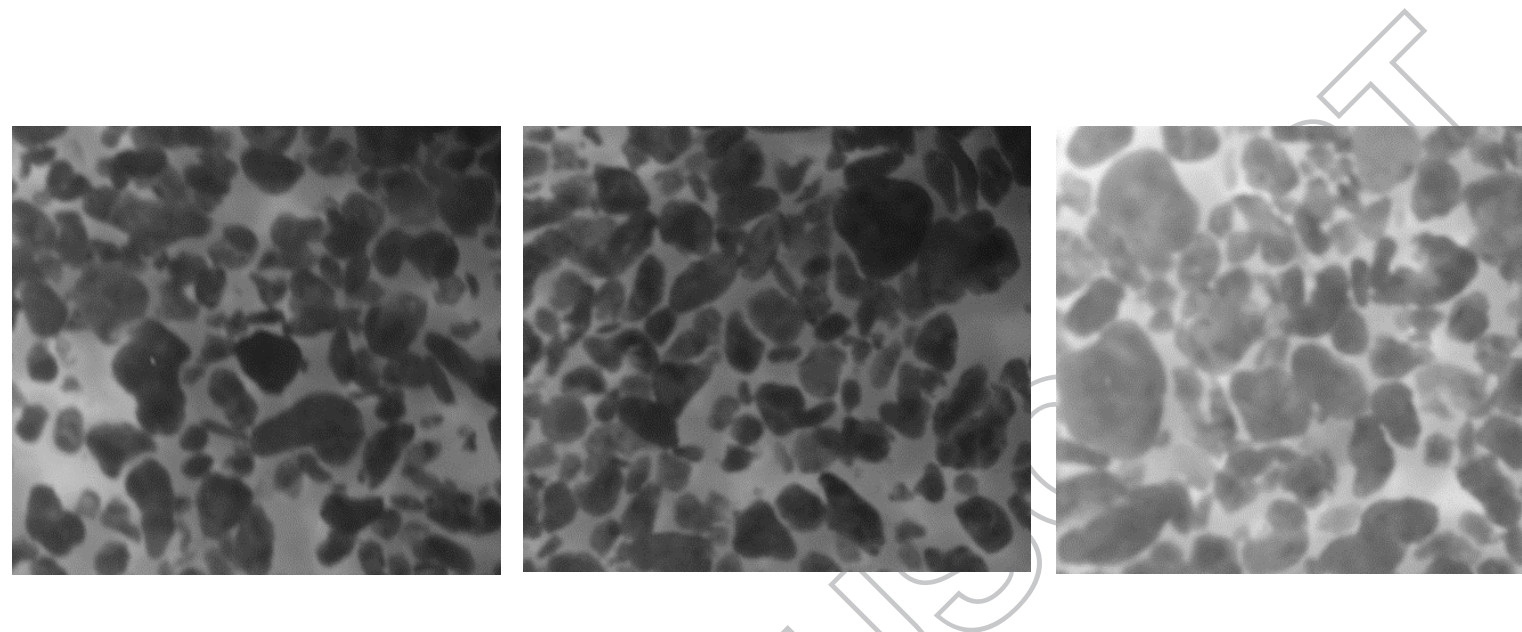

Fig. 5. AGS morphology at the end of granulation phase (Phase II).

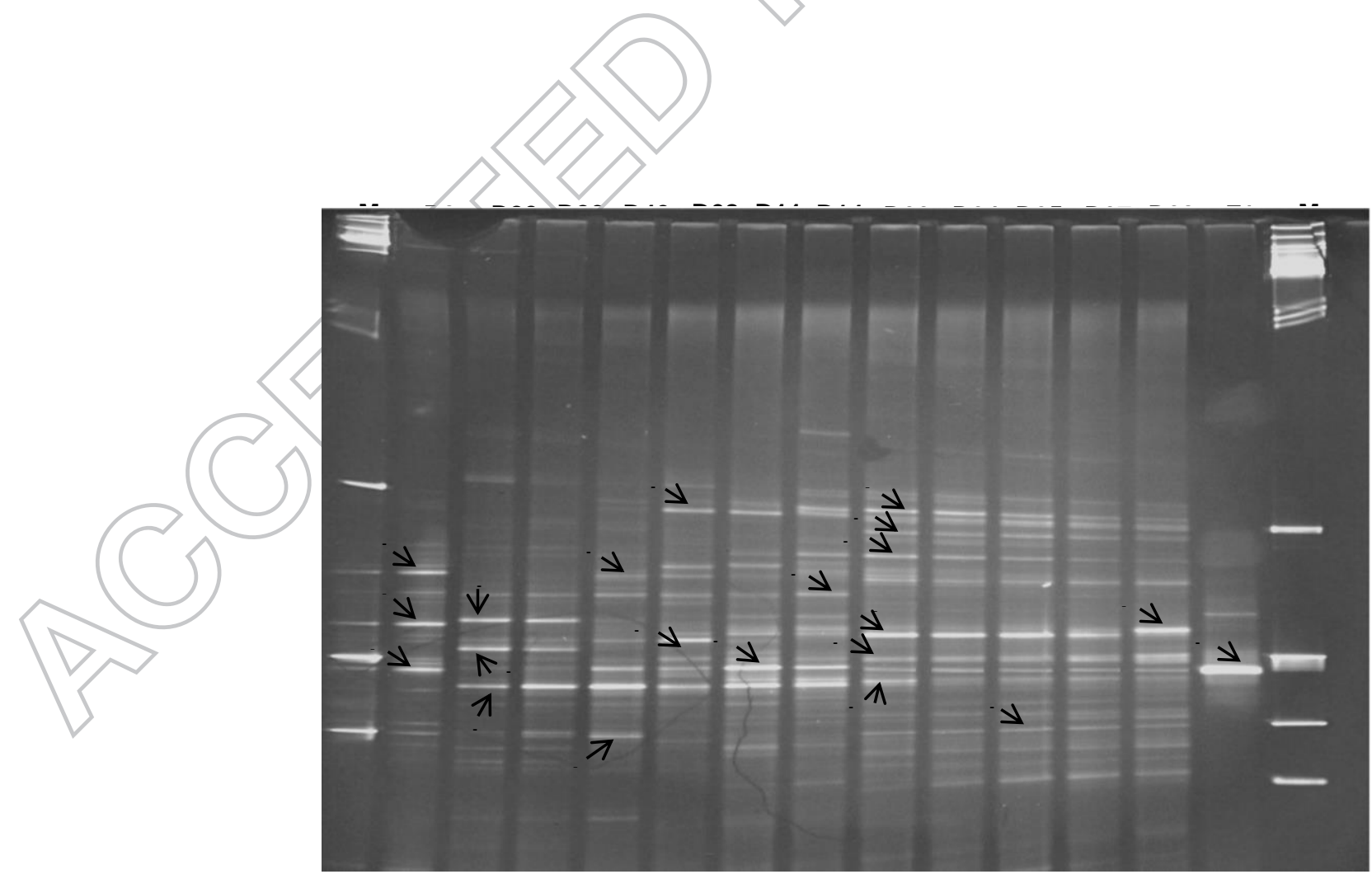


Fig. 6 DGGE community fingerprint of the SBR 16S rRNA gene population along AGS-SBR operation. The collection day is indicated above each lane. Lane M: DNA marker. Bands that were excised for sequence analysis, indicated with an arrow, are labelled with the same number as in Table 4.

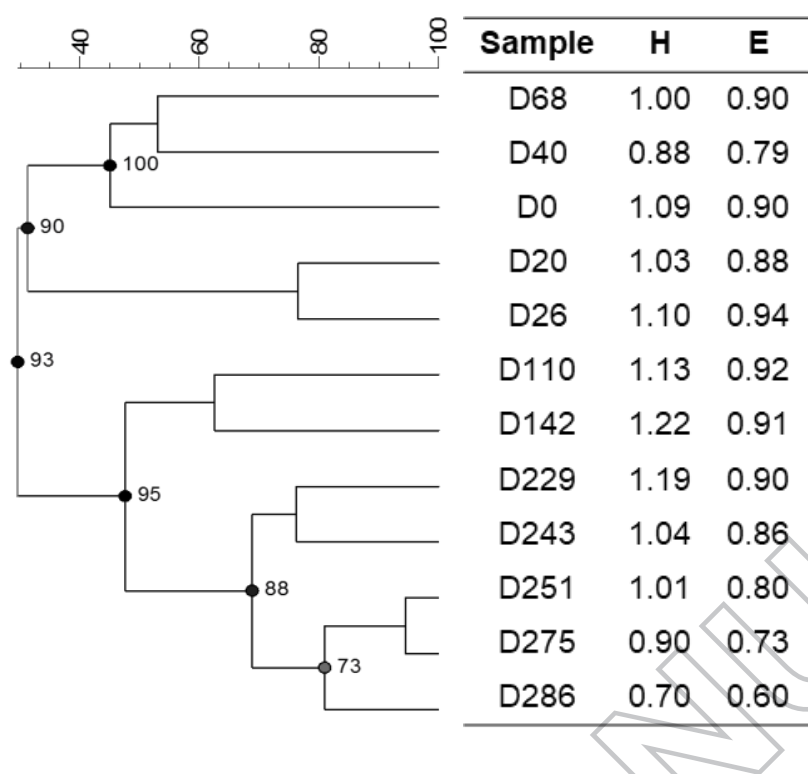

Fig. 7 Cluster analysis of bacterial communities of AGS-SBR based upon DGGE profiles and Shannon diversity $(\mathrm{H})$ and Equitability $(\mathrm{E})$ indexes. Similarities were calculated using the Jaccard coefficient. The dendrogram presents the similarity, in percentage, between the DGGE samples. Numbers at nodes represent the cophenetic correlation coefficient values. The $\mathrm{H}$ and $\mathrm{E}$ indexes calculated for each sample day are included along the respective lane.

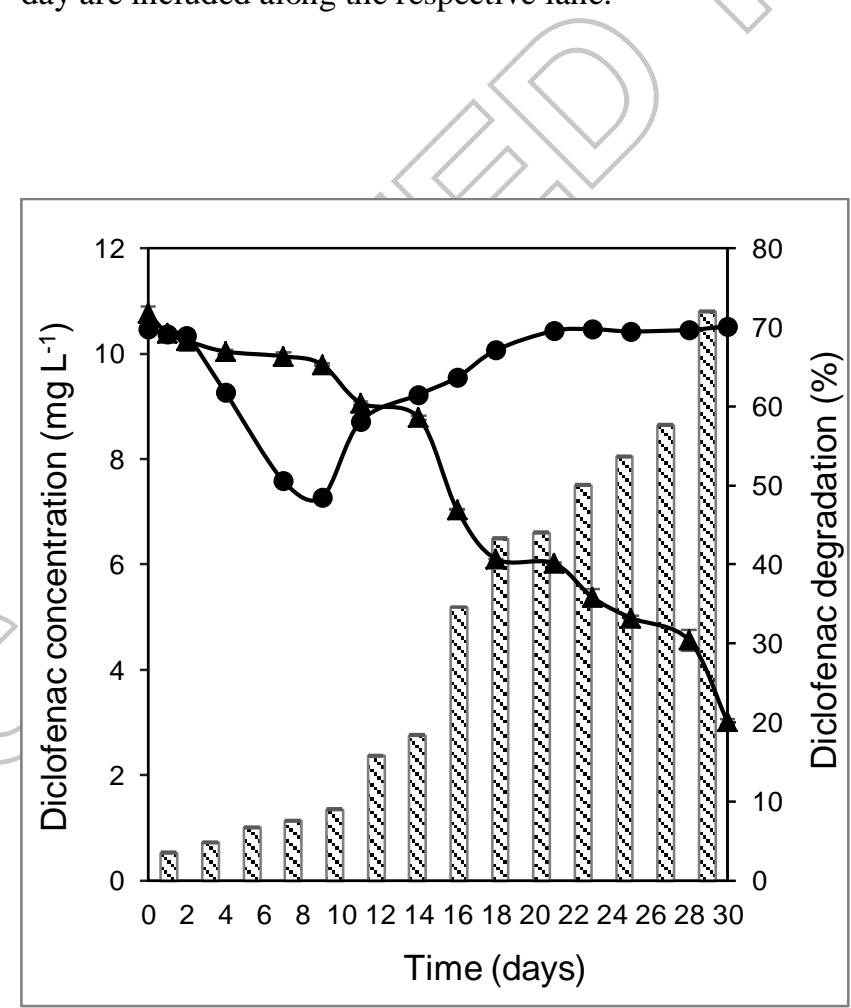

Fig. 8 Diclofenac degradation profile during batch assays using AGS. Bars indicate the percentage of diclofenac removed; Filled triangles indicate diclofenac concentration in $\mathrm{mM}(\boldsymbol{\Delta})$; Arrows indicate the 
feeding with acetate and filled circles indicate diclofenac concentration on an adsorption control assay with inactivated granules $(\bullet)$. Values are means \pm standard error of the mean (SEM).

Table 1. Operating conditions for each phase in the AGS-SBR.

\begin{tabular}{|c|c|c|c|c|c|c|c|}
\hline \multirow{3}{*}{ Phases } & \multicolumn{7}{|c|}{ Operating Conditions } \\
\hline & \multirow{2}{*}{$\begin{array}{l}\text { Length of } \\
\text { operation } \\
\text { (days) }\end{array}$} & \multirow{2}{*}{$\begin{array}{c}\text { Days of } \\
\text { operation }\end{array}$} & \multirow{2}{*}{$\begin{array}{c}\text { Cycle } \\
\text { time } \\
(\mathbf{m i n})\end{array}$} & \multirow{2}{*}{$\begin{array}{c}\text { Anaerobic } \\
\text { feeding } \\
\text { (min) }\end{array}$} & \multirow{2}{*}{$\begin{array}{c}\text { Aeration } \\
\text { (min) }\end{array}$} & \multicolumn{2}{|c|}{$\begin{array}{l}\text { Inlet Carbon sources } \\
\text { Concentrations (mM) }\end{array}$} \\
\hline & & & & & & Acetate & DCF \\
\hline I & $0-19$ & 20 & 180 & - & 180 & 5.9 & 0.03 \\
\hline II & $20-97$ & 78 & 180 & 60 & 85 & 5.9 & 0.03 \\
\hline III & $98-193$ & 96 & 180 & 60 & 112 & 5.9 & $\theta$ \\
\hline $\mathrm{IV}^{\mathrm{a}}$ & 194-228 & 35 & 180 & 60 & 112 & 5.9 & 0.03 \\
\hline $\mathrm{V}^{\mathrm{a}}$ & $229-256$ & 28 & 360 & 60 & 292 & 5.9 & 0.03 \\
\hline VI & $257-286$ & 30 & 360 & 60 & 292 & 5.9 & 0 \\
\hline${ }^{\mathrm{a}} \mathrm{DCF}$ a & ied 1 cycle/48 & & & & & & \\
\hline
\end{tabular}

Table 2. Aerobic granular sludge properties along bioreactor operation

\begin{tabular}{|c|c|c|c|c|c|}
\hline Phase & MLSS $\left(\mathbf{g ~ L}^{-\mathbf{1}}\right)$ & MLVSS (g L-1) & MLVSS/MLSS & $\mathbf{S V I}_{\mathbf{5}}\left(\mathbf{m l} / \mathbf{g}_{\mathbf{S S T}} \mathbf{- 1}^{\mathbf{1}}\right)$ & SRT (d) \\
\hline II & 30.6 & ND & ND & 22.0 & ND \\
\hline III & 32.4 & ND & ND & 21.8 & ND \\
\hline IV & 16.2 & 15.2 & 0.94 & 18.8 & 18.3 \\
\hline V & 7.79 & 5.90 & 0.76 & 49.6 & 30.8 \\
\hline VI & 14.6 & ND & ND & 53.1 & ND \\
\hline
\end{tabular}

MLSS, mixed liquor suspended solids; MLVSS, mixed liquor volatile suspended solids; SRT, sludge retention time; $\mathrm{SVI}_{5}$, sludge volume index after 5 min of settling; ND, Not determined.

Table 3. Phylogenetic affiliation and similarity to the closest relative of bacterial isolates extrated from the aerobic granules

\begin{tabular}{|l|c|c|c|c|c|c|}
\hline Isolate & $\begin{array}{c}\text { NCBI } \\
\text { accession nr. }\end{array}$ & $\begin{array}{c}\text { Phylogenetic } \\
\text { affiliation }\end{array}$ & Closest relative (accession nr.) & $\begin{array}{c}\text { Similarity } \\
(\%)\end{array}$ & Isolation source & $\begin{array}{c}\text { Degradation } \\
(\%)\end{array}$ \\
\hline SBR_1 & MT193506 & Actinobacteria & Microbacterium hominis strain SJTG1 (MH180761) & 99 & n. d. & 22 \\
\hline SBR_2 & MT193507 & a-Proteobacteria & Starkeya sp. SBR22(KC936274) & 100 & aerobic granular sludge reactor & 28 \\
\hline SBR_3 & MT193508 & $\gamma$-Proteobacteria & Serratia sp. NB2 (HQ917058) & 100 & nitrobenzene-contaminated soil & 27 \\
\hline SBR_4 & MT193509 & Actinobacteria & Rhodococcus qingshengii strain S521B-49(HQ238487) & 100 & fermenting grain & 19 \\
\hline SBR_5 & MT193510 & Bacteroidetes & Flavobacteriaceae bacterium HJX21(KP979552) & 99 & river water & 34 \\
\hline SBR_6 & MT193511 & a-Proteobacteria & Rhizobium sp. HW-2(KP152651) & 99 & coal & 33 \\
\hline SBR_7 & MT193512 & $\gamma$-Proteobacteria & Pseudomonas sp. strain Gamma-81 (MH703512) & 99 & soil & 25 \\
\hline SBR_8 & MT193513 & $\gamma$-Proteobacteria & Pseudoxanthomonas sp. strain DMAJP25(KX817875) & 99 & soil & 33 \\
\hline SBR_9 & MT193514 & $\beta$-Proteobacteria & Chitinimonas taiwanensis strain fA3(FJ947053) & 99 & sewage of a waste water treatment plant & 27 \\
\hline SBR_10 & MT193515 & $\beta$-Proteobacteria & Acidovorax sp. strain R022 (MH569472) & 100 & groundwater & 25 \\
\hline SBR_11 & MT193516 & a-Proteobacteria & Rhizobiales bacterium R0i51(EF219048) & 99 & membrane biofilms treating MBR effluent & 20 \\
\hline n. d. - not determined & & & & & \\
\hline
\end{tabular}


Table 4. Phylogenetic affiliation and similarity to the closest relative of bacterial strains isolated from SBR

\begin{tabular}{|c|c|c|c|c|c|c|c|c|c|}
\hline \multirow{2}{*}{ Isolate } & \multirow{2}{*}{$\begin{array}{l}\text { Phylogenetic } \\
\text { affiliation }\end{array}$} & \multirow{2}{*}{ Closest relative (accession $\mathrm{nr}$.) } & \multirow{2}{*}{$\begin{array}{c}\text { Similarity } \\
(\%)\end{array}$} & \multirow{2}{*}{ Isolation source } & \multicolumn{5}{|c|}{ Isolation phase } \\
\hline & & & & & I & II & III & $\mathrm{V}$ & VI \\
\hline b1 & Unknown & Uncultured bacterium clone OTU 89 (KX652496) & 97 & n.d. & $\sqrt{ }$ & & & & \\
\hline b2 & $\beta$-Proteobacteria & Uncultured beta proteobacterium (KC633461) & 100 & activated sludge of a full-scale WWTP & $\sqrt{ }$ & & & & \\
\hline b3 & $\alpha$-Proteobacteria & Labrys portucalensis strain F11 (A Y362040.1) & 99 & contaminated sediment & $\sqrt{ }$ & $\sqrt{ }$ & $\sqrt{ }$ & $\sqrt{ }$ & $\sqrt{ }$ \\
\hline b4 & Unknown & Uncultured bacterium clone PHA88 (JQ658336.1) & 97 & PHA-accumulating mix culture & & $\sqrt{ }$ & $\sqrt{ }$ & & \\
\hline b5 & $\gamma$-Proteobacteria & Azomonas macrocytogenes strain ICMP 4308 (EF122433) & 0.99 & n.d. & & $\sqrt{ }$ & & & \\
\hline b6 & $\beta$-Proteobacteria & Thauera sp. LOPT-10-14 gene (LC145286) & 100 & wastewater treatment plant & & & & & \\
\hline b7 & Unknown & Uncultured bacterium is olate (KU258296) & 97 & $\mathrm{~A} 2 \mathrm{O}$ reactor & & & & & \\
\hline b8 & $\beta$-Proteobacteria & Thauera aromatica strain M11 (MH665743) & 96 & n.d. & & & & & \\
\hline b9 & Bacteroidetes & Uncultured Chitinophagaceae bacterium clone 3c_35699 (MG803158) & 96 & sewage sludge & & & $\sqrt{ }$ & $\sqrt{ }$ & $\sqrt{ }$ \\
\hline b10 & Firmicutes & Uncultured Dialister sp. isolate DGGE gel band G32 (KU877511) & 89 & fecal sample & & & & & \\
\hline b11 & $\alpha$-Proteobacteria & Labrys portucalensis strain F11 (A Y362040.1) & 99 & contaminated sediment & & & $\sqrt{ }$ & $\sqrt{ }$ & $\sqrt{ }$ \\
\hline b12 & Unknown & Uncultured bacterium clone MABRDTU39 (FJ529992) & 79 & counter-diffusion biofilm & & & $\sqrt{ }$ & & \\
\hline b13 & $\beta$-Proteobacteria & Uncultured Nitrosomona s sp. clone isolate DGGE gel band (MH333199.1) & 92 & Nitrifying MBR & & & $\sqrt{ }$ & $\sqrt{ }$ & $\sqrt{ }$ \\
\hline b14 & Bacteroidetes & Uncultured Niabella sp. (MG803287) & 96 & sewage sludge & & & & $\sqrt{ }$ & $\sqrt{ }$ \\
\hline b15 & Bacteroidetes & Bacteroidetes bacterium MA051 (FJ377378) & 97 & n.d. & & & $\sqrt{ }$ & $\sqrt{ }$ & $\sqrt{ }$ \\
\hline b16 & $\gamma$-Proteobacteria & Lysobacter sp. strain WW223 (MH591530) & 100 & Well Water & & & & $\sqrt{ }$ & $\sqrt{ }$ \\
\hline b17 & Firmicutes & Uncultured Dialister sp.(KU877511) & 88 & n.d. & & & & $\sqrt{ }$ & $\sqrt{ }$ \\
\hline b18 & $\beta$-Proteobacteria & Uncultured beta proteobacterium (HE856422) & 87 & microbial fuel cell & & & & $\sqrt{ }$ & $\sqrt{ }$ \\
\hline b19 & Unknown & Uncultured bacterium clone Sample_1C1_Contig_23 (KJ633531) & 82 & waste deposit soil sample & & & & $\sqrt{ }$ & $\sqrt{ }$ \\
\hline b20 & $\gamma$-Proteobacteria & Tahibacter aquaticus (AM981202) & 98 & drinking water network & & & & & \\
\hline b21 & $\alpha$-Proteobacteria & Labrys portucalensis strain F11 (AY362040.1) & 99 & contaminated sediment & $\sqrt{ }$ & $\sqrt{ }$ & $\sqrt{ }$ & $\sqrt{ }$ & $\sqrt{ }$ \\
\hline
\end{tabular}

